\title{
Tax Expenditures in Local Taxes - an Effective Instrument of Local Tax Policy? The Example of Poland
}

\author{
Paweł Felis ${ }^{1}$ and Grzegorz Gołębiowski²
}

\begin{abstract}
This study examines the size and diversity of tax expenditures (TEs) by gminas (municipalities) in Poland between 2007 and 2019. Consequences of gminas' taxing power and the reduction of revenues resulting from statutory tax preferences were taken into account. To analyze the data, we used: scatter graphs (showing the relationship between two selected variables) and plot graphs (showing the course of the values of the studied variables over time, to show the dynamics of the phenomena). The scatter graphs showed, sometimes strong, linear correlative relationships. No clear curvilinear relationships were found, therefore we applied Pearson correlation. Gminas used TEs to a small but also highly variable extent. The factors determining their use involved: the type and potential of the gmina; the type of local tax. The research hypothesis was partially positively verified. The increase in the incremental \% of TEs' share in tax revenue has a positive impact on the incremental trend of revenue growth in the following year. The use of TEs in real estate and vehicle taxes may have strengthened the revenue potential of some gminas in the consecutive years.
\end{abstract}

KEY WORDS: $\quad$ Tax expenditures, local authority tax policy, local taxes.

JEL Classification: E62, H71, H72, R51.

SGH Warsaw School of Economics, Poland'

University of Economics and Human Sciences in Warsaw, Poland ${ }^{2}$

\section{Introduction}

The idea of tax expenditures - an instrument of fiscal policy - is a functioning concept in the theory of taxation, which in recent decades became one of the main subjects of scientific research and economic analysis. Research undertaken in this area may provide a body of important data in the context of solutions applied in the construction of tax systems. After all, the tax system - as an important element of fiscal policy of a country - should be characterized by functionalities,

Correspondence concerning this article should be addressed to:

Paweł Felis, SGH Warsaw School of Economics, Institute of Finance, ul. Madalińskiego 6/8, 02-513 Warsaw, Poland. E-mail: pfelis@sgh.waw.pl within which certain relations occur that serve the entire socio-economic policy (Raczkowski, 2016). On the one hand, there is the relationship between the allocative efficiency of the tax system and redistributive justice, on the other hand, the rational level of fiscalism, the efficiency of the public sector, and the stable, balanced development of individual economies.

Tax expenditures are tax incentives separated from the group of tax preferences, the purpose of which is to bring about a specific effect, namely change the behavior of taxpayers. Thus, the makers of a tax system use specific tax tools that promote rationality of action, stimulating the achievement of the desired economic and social effects. In this 
context, we are dealing with a process of stimulating entities to respond to the effects of the application and operation of a given financial instrument. These reactions can vary and depend on an entity's sensitivity to the object targeted by the instrument. Moreover, the role of fiscal stimulation in the theory of finance is not treated in a uniform way.

There are different models of local government in Europe - different in federal, regional, and unitary states. In unitary countries, such as Poland, there are no divisions characteristic of federal countries - territorial division into countries or their equivalents. There are also no divisions characteristic of regional countries - into autonomous regions. Thus, there is no state level as an intermediate level between the central and local levels. Among local government revenues, local taxes play an important role, but their fiscal importance varies across European countries. The growing role of such revenues is a manifestation of increasing independence and income stability of local government units.

Tax expenditures can be used in the construction of all taxes - both state and local. From the point of view of the local units analyzed in the current study, both fiscal effects of tax expenditures applied in state taxes and local taxes are important. The sources of revenue of gminas in Poland include, among others, revenues from local taxes and from shares in income taxes constituting the state budget income: PIT and CIT (Ustawa z dnia 13 listopada 2003 o dochodach jednostek samorządu terytorialnego [Act of 13 November 2003 on revenues of local government units], 2003).

Local taxes are an important element of selfgovernance. Thanks to them, gmina authorities can influence the development of revenue sources and shape their amounts. In Poland, however, the most important local taxes are associated with the so-called limited taxing power, determined, on the one hand, by the constitutional principle of tax adoption by parliament, and on the other, by the right of gminas to set the amount of local taxes according to the law (Felis \& Otczyk, 2021).

The current study considers the size and diversity of tax expenditures' use ${ }^{1}$ in Polish gminas, in those local taxes in which the gminas can shape certain aspects of their construction such as: real estate tax, agricultural tax, forest tax, and tax on means of transport. The study of the use of tax expenditures takes into account both the fiscal effects of gminas' taxing power and the reduction of revenues resulting from statutory tax preferences used in the construction of these taxes.

The scope of use of the limited taxing power granted to gminas allowed the authors to answer the following research questions:

1. Have gminas pursued an active tax policy, making full use of the prerogatives of their taxing power?

2. What factors were important in differentiating local tax policy?

The detailed analysis also made it possible to examine the effectiveness of tax expenditures in the context of achieving one of the goals of local tax policy - strengthening the revenue potential of gminas in Poland. The following research hypothesis was verified:

1. The use of tax expenditures by gminas in Poland may have some impact on building and strengthening their revenue potential in subsequent years.

The article uses methods typical for social sciences, which involve empirical cognition (observation, comparison, and measurement). The available literature on the subject was used, and own research was carried out on the basis of databases of Poland's Ministry of Finance. Pearson correlation analysis was conducted to indicate the impact of local tax policy on the revenue potential of gminas. The analyses of gminas' use of tax expenditures to achieve other goals of local tax policy were complemented by the results of survey analyses.

\section{Literature Review}

The concept of tax expenditure is attributed to S. Surrey, who promoted this solution assigning it the same role as direct budgetary expenditure (Wyszkowski, 2010). According to Burman, Surrey's main aim was trigger a discussion in the hope that it would initiate a reform of the tax system towards strengthening its main function, that is, the fiscal function (Burman, 2003). 
The term tax expenditure has no equivalent in the Polish language. In most cases it means fiscal privileges that are granted to specific groups of taxpayers or specific spheres of activity, leading to a reduction of the tax burden (Wyszkowski, 2010). However, the definition of this concept is not uniform in the international literature. When formulating a definition of this concept, the above approach of S. Surrey, considered to be a precursor of research in this area, was usually referred to. In other words, definitions are formulated around the issue of expenditures realized by the tax system - spending programs and its two distinct parts. In the first place, the concept of tax expenditure is defined within the framework of taxes that are important for state finances, including the finances of local government units. However, it is sometimes used in the contexts and analyses covering not only the tax system but also other fiscal burdens, for example, social insurance (Wyszkowski, 2012).

The vast majority of research conducted, however, focuses on the government sector in public finance. Lehn M. Benjamin and Paul L. Posner indicate that tax expenditures have become a common fiscal policy tool of the United States government. (Benjamin \& Posner, 2018). The concept of tax expenditures is often used by governments to stimulate investment, innovation, and employment, although according to Redonda and other researchers, public policies that incorporate these arrangements are largely opaque, costly, and often ineffective in achieving their objectives. They also cause undesirable side effects (Redonda et al., 2019). Barrios et al. point out that the use of tax credits within the scope of tax expenditures is tantamount to indirect public spending through which certain social and economic objectives are achieved (Barrios et al., 2020). In another study, Barrios et al. point out that tax expenditures applied in tax systems in EU Member States redistribute resources in favor of women and people with low education levels (Barrios et al., 2020). Although Bykov and Zimmermann believe that tax expenditures are less effective than direct expenditures, they do not question their indirect nature (Bykov \& Zimmermann, 2018). Nevertheless, researchers usually agree that tax policy is a powerful financial tool that can serve to achieve economic goals (Gurdal et al., 2021). To be more effective, fiscal policy (understood as the impact of taxes and public spending) should go hand in hand with the development of strong institutions. The combination of these two areas is key to ensuring the long-term economic growth of countries (Arvin et al., 2021).

There is no doubt that tax solutions can be stimulating in terms of the adopted structures and taxation models. In this regard, and in view of the need for sustainable development, research pays attention to the use of tax expenditure as one of the possible ways to shape public policy. Pérez and Vence recommend systemic tax reforms in a way that supports the transition towards a sustainable economy (López Pérez \& Vence, 2021). Following this narrative, Redonda and other researchers suggest phasing out those tax expenditures that are harmful to the environment, including tax incentives for fossil fuels and other programs that promote unsustainable use of natural resources (Redonda et al., 2019).

The concept of tax expenditures in the context of local governments' finances is recent and largely unexplored. M. Banaszewska undertook research regarding the topic. On the basis of analysis of real estate taxes in Polish gminas in 2005-2017 she showed that tax expenditure (preferential tax policy) has a small impact on gminas' incomes. In her view, it is a political rather than an economic tool (Banaszewska, 2021). In terms of other research, John W. Decker, based on a panel data analysis using data from 67 Florida counties between 2008 and 2017, showed that the age of the population in a district (county) determines real estate tax rate decisions in the area (Decker, 2021).

\section{Nature and Methodology of Identification of Tax Expenditures in Local Taxes}

Gminas in Poland are financed with specific own revenues, which include, among others, local taxes, shares in revenues from state budget taxes, and revenues from property. They are insufficient to cover expenditures, hence gminas receive transfers from the state budget in the form of general subvention and subsidies. Local taxes are one of the components of gminas' financial systems, constituting an important category of own revenue sources - revenue that determines the scope of their financial independence. However, from the point of view of self-governance of local communities, their content is important - the transfer of the 
majority of the tax base to gminas' local taxing power (Felis, 2014).

Several local taxes can be distinguished in the budgets of Polish gminas, but gminas' authority regarding those taxes varies (Felis \& Rosłaniec, 2019). Table 1 shows the instruments of legal authority of gminas with respect to two groups of local taxes. The first one (active taxing power - partially restricted) includes taxes where the gminas may shape certain elements of their structure (real estate tax, agricultural tax, forest tax, and tax on means of transport). The second one (passive taxing power - severely limited) includes taxes which fully constitute gimnas' revenues, but gminas' cannot shape their construction (tax on civil law transactions, tax on inheritance and donations, fixed amount tax). It is worth noting that local authorities can shape tax rates in two ways, namely:

- directly by determining their amount - this concerns taxes on real estate and means of transport,

- indirectly, using the so-called stabilizers - in the case of the agricultural tax rate by reducing the purchase price of rye, and in the case of forest tax by reducing the purchase price of timber.

From the point of view of the tax expenditures, it is important that the gmina council - within the scope of its statutory powers - shapes those structural elements that affect the amount of the tax liability of the taxpayer (reduction or differentiation of tax rates, expansion of the statutory catalogue of tax exemptions or reliefs). Taxing power may also be exercised by the executive body of gminas (the wójt [highest representative of the gmina], the mayor, or the president of a town/city $)^{2}$.

The obvious effect of an active taxing power granted to gminas is reduced tax revenue. However, gminas' tax policy is one of the basic tools for implementing public tasks at the local level. Municipal authorities, therefore, by making decisions regarding the maximum reduction of the tax burden, stimulate socio-economic development and give up a certain

Table 1

Gminas' Authority Concerning Particular Local Taxes

\begin{tabular}{|c|c|c|c|}
\hline Type & $\begin{array}{l}\text { Setting rates within } \\
\text { statutory limits }\end{array}$ & Introduction of reliefs & Introduction of exemptions \\
\hline Real estate tax & YES & NO & $\begin{array}{c}\text { YES } \\
\text { (object-based only) }\end{array}$ \\
\hline Agricultural tax & YES & $\begin{array}{c}\text { YES } \\
\text { (object-based only) }\end{array}$ & $\begin{array}{c}\text { YES } \\
\text { (object-based only) }\end{array}$ \\
\hline Forest tax & YES & NO & $\begin{array}{c}\text { YES } \\
\text { (object-based only) }\end{array}$ \\
\hline Tax on means of transport & YES & NO & $\begin{array}{c}\text { YES } \\
\text { (object-based only) }\end{array}$ \\
\hline $\begin{array}{l}\text { Tax on economic activity of } \\
\text { natural persons paid in the } \\
\text { form of a fixed amount tax }\end{array}$ & $\mathrm{NO}$ & NO & NO \\
\hline Inheritance and donation tax & NO & NO & NO \\
\hline Tax on civil law transactions & NO & NO & NO \\
\hline
\end{tabular}

Source: compiled on the basis of the Act on Local Taxes and Fees (1991), the Act on Agricultural Taxes (1984), the Act on Forest Taxes (2002), the Act on Civil Law Activities Tax (2000), the Act on Inheritance and Donation Tax (1983), the Act on Lump Sum Income Tax on Certain Incomes Earned by Natural Persons (1998). 
part of potential revenues (Brzozowska \& KogutJaworska, 2016).

Local taxes include categories of real estate taxation depending on property type (the system of real estate taxation - real estate tax, agricultural tax, forest tax, and taxation of movable property - tax on means of transport). Table 2 shows the design elements of these taxes that determine their fiscal potential the most. However, it should be noted - as will be shown in the empirical part of the study - that potential varies greatly.

In Poland, as in most European countries, the biggest and the most important source of gminas' own revenue among local taxes is the real estate tax. The basic feature of the Polish real estate tax is that the taxable base for land and buildings is not, as in the vast majority of European countries, the value of the property but its area. The adoption of such a tax base undoubtedly results in a considerable simplification of the tax burden and in savings in administrative and compliance costs for taxpayers. However, the negative phenomena of such a solution cannot be neglected (Felis et al., 2019). These include, among others, the unsatisfactory level of realized objectives and tasks set for the system of real estate taxation from the point of view of justice (no possibility to assess the use buildings, their equipment, location) and efficiency (limited influence on rational transformations in the spatial structure of cities, less favorable impact on local finances).

Agricultural tax is a specific - by European standards - construction. The economic criteria of its dimension are crucial (Felis et al., 2018). The tax base is the use value of land, determined by numerical coefficients. They are the same for any holding under similar economic and natural conditions. Hectare standards characterize the use value of land taking into account the differential ground rent (valuation class and type of agricultural land). The amount of tax charged is a fixed rate and depends on the status of the land. There are certain tax preferences in the tax.

\section{Table 2}

Selected Structural Elements of Local Taxes Regulated by Law

\begin{tabular}{|c|c|c|c|}
\hline Tax & Object of taxation & Tax base & Tax rates \\
\hline \multirow[t]{6}{*}{ Real estate } & Land; & Surface area expressed in $\mathrm{m} 2$ & Maximum, differentiated amounts per $1 \mathrm{~m} 2$ \\
\hline & & & of land area; \\
\hline & Buildings or parts thereof; & Usable area expressed in $\mathrm{m} 2$; & Maximum, differentiated amounts per $1 \mathrm{~m} 2$ \\
\hline & & & of usable building area; \\
\hline & Buildings or parts thereof & & \\
\hline & related to an economic activity & Depreciation or market value & $2 \%$ of the building value \\
\hline \multirow[t]{4}{*}{ Agricultural } & Land (agricultural areas) of the & Number of converted ha; & The cash equivalent of 2.5 quintals of rye per 1 \\
\hline & holding; & & ha of agricultural land; \\
\hline & Other land (agricultural areas) & Number of ha as in the land and & The cash equivalent of 5 quintals of rye on 1 \\
\hline & & building register & ha of land \\
\hline \multirow[t]{2}{*}{ Forest } & Forests & Forest area, expressed in ha, as per & Equivalent of $0.22 \mathrm{~m} 3$ of the mean sell price of \\
\hline & & the land and building register & timber by forestry service \\
\hline \multirow{4}{*}{$\begin{array}{l}\text { On means of } \\
\text { transport }\end{array}$} & Trucks; & Means of transport & Maximum, differentiated according to type \\
\hline & Semi-trailer trucks and ballast & & and weight of means of transport or number \\
\hline & tractors; & & of seats on the bus; For the heaviest means of \\
\hline & Trailers and semi-trailers; & & transport there is also a minimum quota \\
\hline
\end{tabular}

Source: own elaboration based on Local Taxes and Charges Act (1991), Agricultural Tax Act (1984), Forest Tax Act (2002). 
In the case of forest tax, the procedure for its assessment is the least complicated. It requires: the forest area expressed in hectares and the timber sales price.

Tax on means of transport is related to the ownership and operation of means of transport indicated by the legislator. The tax base is the number of means of transport owned or registered to the taxpayer. There are maximum rates for certain categories of means of transport and maximum and minimum rates for others.

The concept of tax expenditures has been presented in detail in the literature on the subject, and is explained in the literature review section. The forms of tax expenditures (TEs) and their characteristics are important for further discussion to identify TEs in local taxes. Table 3 contains their basic characteristics - advantages and disadvantages. There is no doubt that constructing TEs, just like all other fiscal policy tools, is very complicated. Due to the multi-directional impact of most tax preferences, an unambiguous assessment of their effectiveness is often impossible. The use of tax tools for stimulation purposes (including tax expenditures) requires certain conditions to be taken into account, such as: correctness of the tax system construction, stability of the introduced tax solutions, feasibility of achieving the goal underlying the introduction of a given instrument, strength and directness of its impact (Matysek, 2011).
Literature review confirms the fact that many ways of classifying tax expenditures have been adopted. An interesting concept, but one that relates to the construction of the personal income tax, has been proposed by Dziemianowicz et al. (2014). Using the proposal of the above-mentioned researchers, and taking into account the most frequently mentioned forms of TEs (indirect reliefs, i.e., deductions from the tax base; direct reliefs, i.e., reduction of the tax amount; exemptions and exclusions of certain tax categories; reduction of tax rates; deferment of tax payment), tax expenditures in local taxes include:

- powers resulting from the taxing power granted to local entities, allowing them to shape specific elements of the tax structure, and

- special preferences built into their structures (certain subjective exemptions, investment allowances and the possibility of tax refunds).

For local units the determinant of the freedom and possibility to create their own tax policy is - as mentioned - the taxing power. Although in Poland the taxing power of gminas is limited, it allows them to directly affect the levels of their own revenues ${ }^{3}$.

In the case of the real estate tax, gmina councils have the right to shape the rates on their own - by lowering or maintaining them at the statutory level. The scope of taxing power also includes the power to differentiate tax rates within particular groups of

\section{Table 3}

Characteristics of Tax Expenditures (TES)

\begin{tabular}{|c|c|}
\hline Criterion & Characteristic \\
\hline Accessibility for beneficiaries & Simple, due to their automatic nature. \\
\hline Administrative costs & Low for exemption, but high for the tax system as a whole because they make it more complex. \\
\hline Possible abuses & Room for evasion and avoidance, and for rent seeking. \\
\hline Flexibility & Works with permanent laws, thereby generating stability but also inertia. \\
\hline Transparency and accountability & Their automatic nature does not contemplate control mechanisms or accountability. \\
\hline Expenditure control & Expenditure determined ex post, uncertain and unlimited, which can cause fiscal imbalances. \\
\hline Effectiveness & Additionality in the targeted action cannot be guaranteed. Inframarginal cases are financed. \\
\hline Equity & Only those who pay taxes accede, and those with greatest income benefit the most. \\
\hline
\end{tabular}

Source: (Villela, et al., 2010) 
taxable objects. Such decisions may be made taking into account the following criteria: location of the real estate, type of activity, real estate type, purpose and use of real estate, technical condition and age of the buildings. Gminas were also granted the power to introduce tax preferences in the form of subjective exemptions other than those specified in the Act on Local Taxes and Fees.

The powers of the gmina council regarding tax rates on means of transport also come down to determining and varying their amount. When determining the rates for particular types of taxed objects, the gmina council considers in particular: the environmental impact of the means of transport, the year of manufacture, or the number of seats. A good example of the use of non-fiscal functions to influence socio-economic phenomena in a given area are allowances that encourage taxpayers to install equipment in transport vehicles which reduces exhaust gas emissions. However, the powers of the gminas in this respect are more limited than in the case of the real estate tax. Gminas may not interfere with the statutory categories of taxed vehicles, exceed the maximum rates and, or differentiate rates in the case of means of transport, for which minimum rates are provided for. Also in this case, gminas may introduce additional exemptions of subjective character, but not in the case of transport means for which the minimum rates have been provided.

Agricultural and forest taxes are similar in terms of the powers vested in the gmina counscil - the council has an indirect influence on the amount of tax rates. Unlike the taxes analyzed so far - it cannot directly set (reduce) tax rates. As it has already been mentioned, gminas have the power to reduce the average purchase price of rye (used for calculation of the agricultural tax) and the average sale price of timber (used as the basis for setting the forest tax rate). Taxing power is also manifested as the ability of gminas to introduce additional reliefs and exemptions of subjective character in the agricultural tax and subjective exemptions in the forest tax.

To sum up, the category of tax expenditures includes instruments of selective impact - tax rates, exemptions and allowances differentiated for particular categories of taxed objects.
When making decisions on the use of the analyzed solutions, gminas should consider their potential effects - not only socio-economic ones. Tax expenditures may have not only positive but also negative impact on the budgetary situation of gminas (Wyszkowska \& Wyszkowski, 2021). The adoption of low rates and the use of tax credits result in the loss of some revenue. The use of tax expenditures, which are generally costly, should therefore be oriented towards long-run benefits. For example, if aimed at tools for influencing entrepreneurship (mobilizing investment capital, increasing employment), then positive effects for gminas in the long-run (increased tax revenues) can be achieved through the development of active localization (the inflow of new, newly established businesses) and passive localization (increasing the scale of operations of existing businesses). Achieving the adopted objectives of the local tax policy is therefore not without significance for entrepreneurs and the local tax base.

The second group of tax expenditures are reliefs and exemptions introduced directly by the legislator into the local taxes. These preferences are aimed at supporting the socio-economic objectives set by the central government, not necessarily in line with the objectives formulated by the gmina councils. Thus, the fiscal effects of these decisions affect gminas' budgets. This is because the realized tax expenditures restrict the financial resources of gminas coming from local taxes, which are crucial (Dziemianowicz \& Budlewska, 2015).

In the real estate tax there is a very large group of exemptions, among others:

- outbuildings or parts thereof: used exclusively for forestry and fishing activities; located on agricultural holdings and used exclusively for agricultural activities; occupied for running a special agricultural production department,

- wasteland, ecological land, wooded land, with the exception of land used for economic activity,

- buildings and structures occupied by an agricultural producer group entered in the register of such groups and used exclusively for the purposes of sale of products or groups of products produced by agricultural holdings of the group's members.

Among the preferences provided for in the construction of tax on means of transport, an interest- 
ing example of tax expenditures involves solutions concerning means of transport used in the so-called combined transport. A taxpayer may receive a refund based on the number of loaded or unloaded trips ${ }^{4}$. Consequently, combined transport could be used in Poland - similarly to Western European countries to a greater extent. Tax expenditures are used here to reward the reduction of negative impacts on the environment and the condition of road surfaces.

Surprisingly many - considering the archaic construction of this tax - preferences were adopted by the legislator in the construction of agricultural tax. Examples of tax expenditures include certain objectbased exemptions and the investment tax credit. Among others, land of low production values (land development areas), land which, through various processes, is to contribute to the improvement of the agricultural property structure (land intended for the establishment of a new agricultural holding or the enlargement of an existing one to an area not exceeding 100 ha, land of agricultural holdings created from the development of wasteland) were exempted from taxation. However, the investment tax credit consists in the reduction of the tax by a part of the incurred investment expenses (maximum 25\%). A completed investment must be included in a closed catalogue of eligible costs (e.g., construction or modernization of livestock buildings used for raising, breeding, and keeping livestock and facilities for environmental protection; purchase and installation of sprinkler systems, drainage and water supply facilities, facilities for using natural energy sources for production purposes).

In contrast, the fewest tax expenditures are provided for in the forest tax structure. For example, there is the environmental use area exemption.

To sum up, the tax expenditures identified in local taxes constitute an extensive catalogue of solutions used by the authorities at the central and local level to implement specific socio-economic policies.

\section{Research Methodology}

The research covered all gminas in Poland, using data for the years 2007-2019. Statistical data was obtained from the Ministry of Finance's aggregate and unit databases $^{5}$. The data focus primarily on the gminas' own revenues and tools of taxing power in local taxes.
Firstly, the values of tax expenditures in local taxes are presented, with a particular emphasis on the real estate tax. They are categorized according to the types of gminas, including in relation to the size of their income. Among others, the category of own income ${ }^{6}$ and four local taxes, in relation to which the legislator provided a certain scope of taxing power, were considered.

For preliminary data analysis, the following figures were used: scatter graphs (showing the relationship between two selected variables) and plot graphs (showing the course of the values of the studied variables over time, specifically in the 2007-2019 period, to show the dynamics of the phenomena). After graph analysis, Pearson correlation was used to test the linear dependence of the variables, as such (for real estate tax and tax on means of transport) dependencies were clearly visible on the scatter graphs.

Long-period data (13 years) were analyzed (thus, they are cross-sectional and temporal). Potentially, this would have provided the basis for a panel study, but this approach was deliberately abandoned at this stage of the research in order to analyze relationships that could be recognized by other, elementary methods, as the study was primarily intended to identify an interesting research area. The interdependencies found will be analyzed in detail in the future to further explore their nature and significance for the gmina's tax policy. Analyzed initially, for the selected pairs, the variable referring to the size of tax expenditures is time regressed, while the variable referring to tax revenues is not. The scatter graphs showed, sometimes strong, linear correlative relationships. No clear curvilinear relationships were found there either, hence the decision was made to use Pearson correlation. By definition, Pearson's correlation coefficient measures the strength of linear correlation, but in the situation analyzed its use was considered optimal and very similar to the use of rank-order correlations such as Spearman's correlation.

Some analytical studies also adopted the results of surveys conducted at the SGH Warsaw School of Economics 7 . The aim of the current study was to identify the motives and activity of gminas with respect to real estate tax, which was identified as the tax generating the highest revenues (out of all taxes which gminas can affect, i.e., those within their taxing power) A questionnaire was sent via e-mail to 
Table 4

Tax Expenditures in Local Taxes in the 2009-2018 Period ${ }^{8}$

\begin{tabular}{lcccccccccc}
\hline $\begin{array}{l}\text { Tax reliefs and } \\
\text { exemptions }\end{array}$ & $\mathbf{2 0 0 9}$ & $\mathbf{2 0 1 0}$ & $\mathbf{2 0 1 1}$ & $\mathbf{2 0 1 2}$ & $\mathbf{2 0 1 3}$ & $\mathbf{2 0 1 4}$ & $\mathbf{2 0 1 5}$ & $\mathbf{2 0 1 6}$ & $\mathbf{2 0 1 7}$ & $\mathbf{2 0 1 8}$ \\
\hline PLN million & 6337 & 6457 & 7093 & 7761 & 8042 & 8042 & 8089 & 7112 & 7307 & 7770 \\
& & & & & & & & & & \\
\%GDP & 0.47 & 0.47 & 0.47 & 0.49 & 0.49 & 0.46 & 0.45 & 0.38 & 0.37 & 0.37 \\
\hline
\end{tabular}

Source: (Preferencje podatkowe w Polsce [Tax preferences in Poland], 2018).

599 Polish gminas which were selected on the basis of geographical criteria. The intention was to examine gminas with different characteristics located in 3 voivodeships: Mazowieckie, Śląskie, and Podlaskie. Ultimately, the response rate was 54\% (52\% Mazowieckie, 55\% Podlaskie, 58\% Śląskie). This study includes the portion of the survey that focused on tax expenditures.

\section{Data Analysis}

The value of tax preferences reducing the income of local units in the analyzed period did not exceed $0.5 \%$ of GDP (Table 4 ), constituting only about $10 \%$ of the global value of preferences in the Polish tax system. Initially, the value of tax preferences systematically increased, but in recent years tax expenditures have already been characterized by a decreasing trend. The publication by Poland's Ministry of Finance (Tax Preferences, 2018) shows that in 2018 the main areas of support through the system of preferences were, as in previous years, agriculture (PLN 2.3 billion), transport, and environmental protection (PLN 1.9 billion). These preferences accounted for $54.4 \%$ of the value of quantified preferences operating in local taxes. The preferences with the highest value (PLN 4.8 billion, which constituted $61.4 \%$ of all preferences) were the following 3 exemptions (all of them related to real estate tax): outbuildings on agricultural land, used exclusively for agricultural activities; wasteland, with the exception of land occupied for business activities; railway structures and land occupied by them.

An important feature of tax expenditures is, as already emphasized, their use to achieve specific socio- economic objectives. Gminas' tax policies are among the important determinants of the fiscal efficiency of local taxes. The effects of using the prerogatives of taxing power determine the level of tax expenditures in local taxes. Although in Poland the taxing power is in some way limited, it allows them to influence the level of revenue obtained from certain taxes. Taxing power is the power of gminas to reduce and differentiate tax rates on the basis of taxed object, to adopt exemptions and reliefs of a subjective nature, and to remit, spread into instalments, and defer tax payments.

In 2007-2019, the value of tax expenditures in local taxes in Poland amounted to almost PLN 53 billion (Figure 1). By 2015, an increase in the use of local measures was evident. The maximal value of revenue loss occurred in 2015 - just over PLN 4.8 billion. There was a significant decrease in the value of lost municipal revenue from tax expenditures across all local taxes between 2016 and 2017. Another increase can be observed in 2018-2019. However, for example in 2019 compared to the value of 2015, the amount is lower by more than PLN 0.4 billion. Figure 1 also shows that the use of tax expenditures varies greatly depending on the type of gmina. Tax preferences have a much greater impact on revenues in rural and urban-rural gminas than in urban gminas and cities with poviat rights. The largest value of tax expenditures fell on rural gminas - nearly 2 billion in the 2013-2015 period and nearly 1.7 billion in 2019 . The smallest value fell on urban gminas - about PLN 0.6 billion per year. However, if we consider the number of rural (more than 1500) and urban (more than 300) gminas, the conclusions regarding these values 


\section{Figure 1}

Revenue Lost by Polish Gminas due to Tax Expenditures in All Local Taxes in the 2007-2019 Period - Total and by Type of Gmina (in PLN thousand)

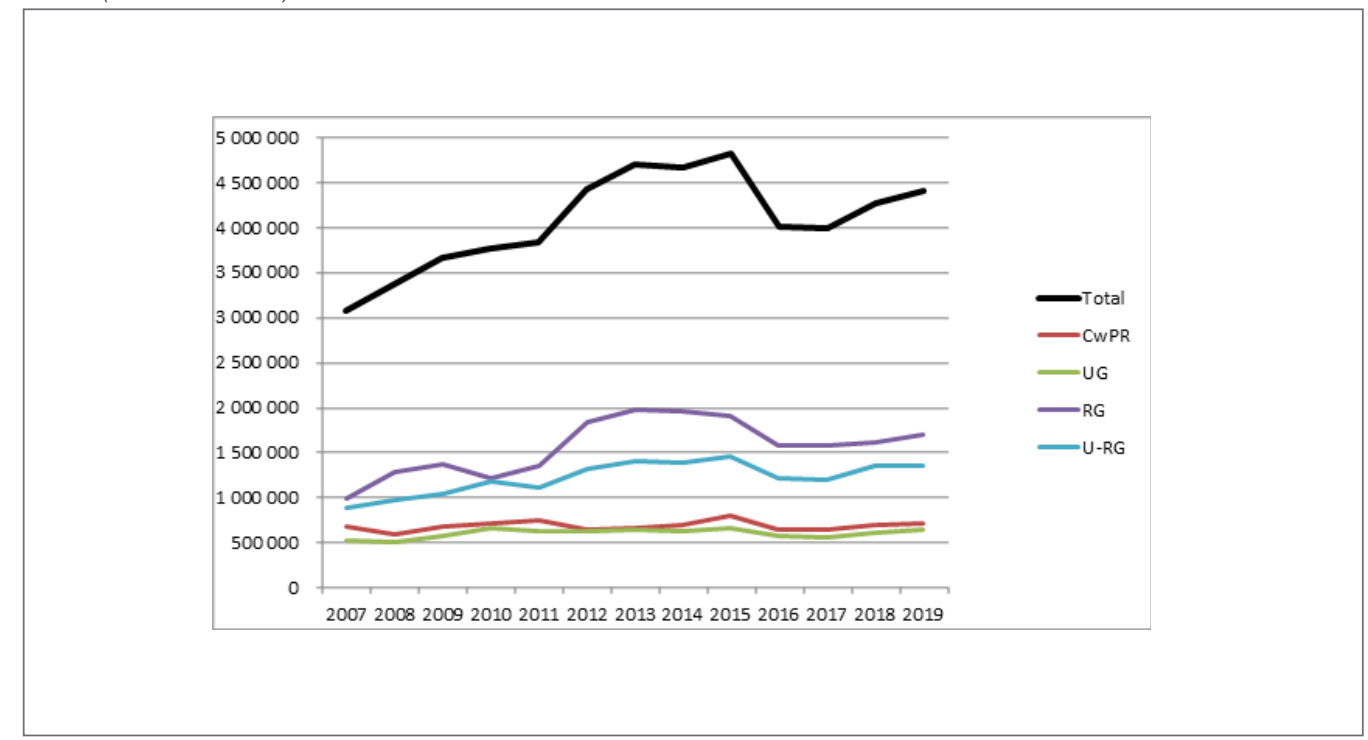

Source: Own compilation based on data from Poland's Ministry of Finance.

are different. Nonetheless, we may assume that the scale of utilization of the analyzed tax instruments is to some extent derived from the potential and resources of particular gminas.

Per capita, rural and urban-rural gminas recorded the highest values in the whole analyzed period, and they were much higher in comparison with urban gminas. Authors of other studies point to interesting reasons to explain this apparent variation in gminas' tax policy (Swianiewicz \& Łukomska, 2016; Wyszkowska \& Wyszkowski, 2021). Large cities, due to the infrastructure and range (distribution and influence of a given facility) are so competitive for entrepreneurs and inhabitants that, in the opinion of the authorities, there is no need to use incentive tools. Moreover, for entrepreneurs - in the opinion of local authorities of gminas - such tax preferences, due to their small amount in relation to the costs of business activity, are not necessarily an attractive incentive. It is also stressed that rural and urban-rural gminas are generally guided by political or social considerations and do not analyze the effects of tax expenditures.
Such active tax policies of small, rural gminas may therefore be the result of strong direct pressure from local communities expecting lower taxation. Motives related to political capital are then key. However, in larger urban areas, characterized by a greater anonymity in authority-citizen relations and a higher voter turnout, these factors no longer play such a role.

It is worth noting that the vast majority of tax expenditures result from the effects of the extensive taxing power provided for and applied in the four local taxes. This was a mean of nearly $98 \%$ tax expenditures of all local taxes for all gminas during the period studied. Therefore, the remainder of the current study is limited to data on the four taxes in question. On average, revenues from these real estate taxes accounted for $34.7 \%$ of own revenues.

The structure of tax expenditures in local taxes of gminas, presented in Figure 3, shows that the most important role was played by the real estate tax - on average, the effects of decisions on this tax accounted for nearly $76.5 \%$ of the effects of decisions across all four real estate taxes during the study period. The 


\section{Figure 2}

Revenue lost by Polish gminas due to Tax Expenditures in All Local Taxes in the 2007-2019 Period - Total and by Type of Gmina (in PLN thousand) per Inhabitant (in PLN)

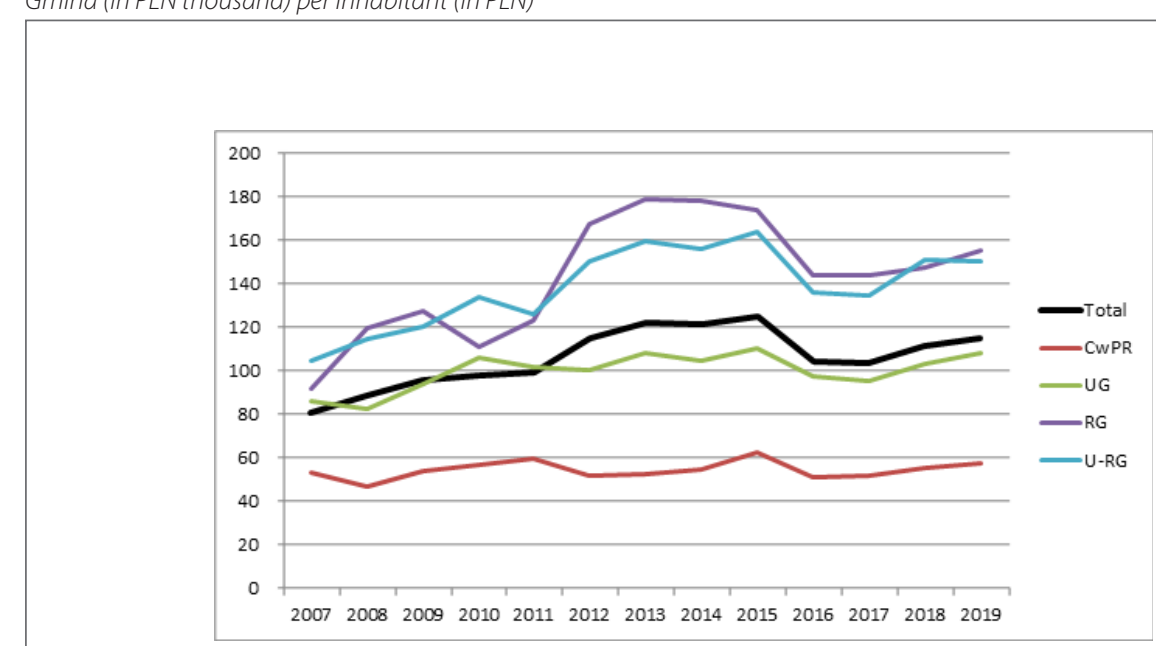

Source: Own compilation based on data from Poland's Ministry of Finance.

share of preferences in agricultural tax varied greatly ( $1.8 \%$ in $2010-16.4 \%$ in 2012 ), which was due to its seasonality (variation in the price of rye - which determined the tax rate). Rural (3.6-28.5\%) and urbanrural gminas (1.7-16.9\%) recorded the highest share of preferences in agricultural tax. The decreasing share of applied preferences in both real estate taxes since 2013 is reflected in the increasing importance of preferences applied in the tax on means of transport (increase from $13.4 \%$ in 2013 to $22.6 \%$ in 2019). In cities with poviat rights more than $36 \%$ of the lost revenue in recent years was specifically due to decisions regarding this tax. It is important to note that this is the only tax (out of all considered in the current study) characterized by a mobile tax base. An increase in the importance of tax expenditures could therefore indicate tax competition between gminas. However, this requires separate in-depth research.

The use of the tools of taxing power causes, in a short period of time, a decrease in revenues from particular public levies. Let us then comment on the effects of gminas' tax policies (expressed in percentages) in the 2007-2019 period (Table 5). The compar- ison of the effects of tax expenditures with various dimensions of own revenue potential ${ }^{9}$ (own revenue and revenue from four local taxes) shows to what extent this revenue could have been higher (by a mean of approximately $7 \%$ and revenue from the said local taxes by approximately 19.5\%) had the gminas not used their taxing power. Initially, almost halfway through studied period, there has been a characteristic upward trend of these indicators. In the latter part, however, the used indicators decreased - as a result, in 2019 the values of both were at a level lower than in 2007. This was caused by the effects of tax decisions mainly in the field of real estate tax and the own revenue potential of gminas in subsequent years (fluctuations in tax growth rate, the share of revenue from the analyzed taxes in own revenue). The effects of tax expenditures in the form of a decrease in the indicated income categories were most noticeable in rural gminas and least noticeable in cities with poviat rights. The share of lost income in own income in rural gminas was almost six times higher than in cities with poviat rights, while the share of lost income in revenues from local taxes was more 
Figure 3

Structure of Tax Expenditures in Local Taxes in 2007-2019 (in \%)

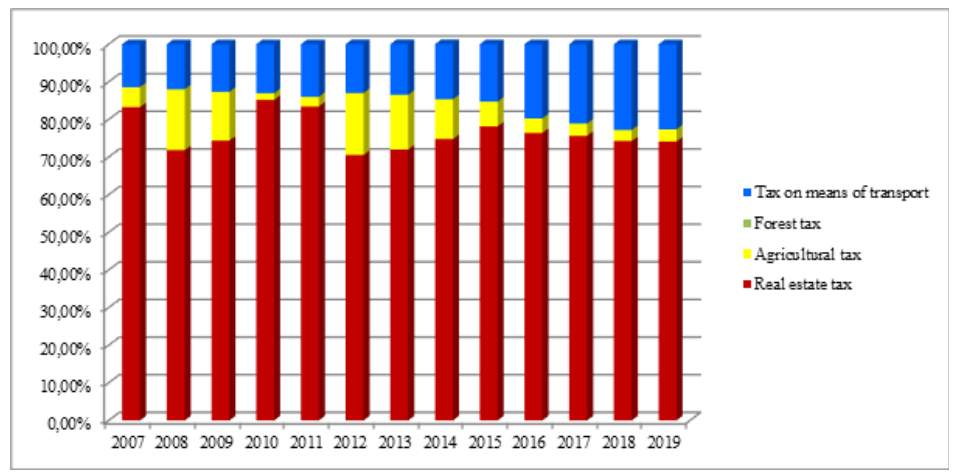

Source: Own compilation based on data from Poland's Ministry of Finance.

than three times higher. In all the examined types of gminas, a clear decrease in the use of tax expenditures can be observed in recent years. As for the relation to own revenue this was, respectively: for cities with poviat rights $(2.89 \% \uparrow 3.03 \% \downarrow 1.78 \%)$, for urban gminas $(7.93 \% \uparrow 9.2 \% \downarrow 5.5 \%)$, for urban-rural gminas $(11.82 \% \uparrow 14.01 \% \downarrow 8.46 \%)$ and for rural gminas $(13.42 \% \uparrow 18.14 \% \downarrow 10.05 \%)$. However, in the case of the relation to revenue from said local taxes these were, respectively: for cities with county rights $(11.47 \% \downarrow 7.48 \%)$, for gminas $(21.33 \% \downarrow 16.19 \%)$, for urban-rural gminas $(26.48 \% \uparrow 29.04 \% \downarrow 21.33 \%)$ and for rural gminas $(27.79 \% \uparrow 35.79 \% \downarrow 25.05 \%)$. Moreover, it is worth noting the changes in the volume of own revenues of gminas and tax expenditures used. Dynamics indicators' values presented in Table 6 partly explain the changes in the discussed scale of the use of tax expenditures in local taxes.

When analyzing the importance of the tools of local tax policy, it must be stressed that gminas made greater use of the power to reduce and differentiate rates $(70 \%$ of preferences on average) than other tools, such as subjective exemptions. The remaining ones, for example, in the form of writing off tax arrears, were applied exceptionally, hence they caused insignificant revenue decreases for gminas.

The real estate tax is the most important source of gminas' own revenues among the local taxes, tax expenditures played the most important role in this respect. Let us take a closer look at the tools used by gminas for this tax. Thanks to this levy, the budgets of gminas were enriched in the 2015-2019 period by, respectively: PLN 20.2 billion; PLN 20.8 billion; PLN 21.8 billion; PLN 22.6 billion and PLN 23.3 billion. The values and their annual changes confirm the stabilizing role of this tax. Revenues generated from this tax - with the current surface tax structure - are relatively insensitive to economic fluctuations. The largest amounts go to cities with poviat rights every year. For instance, in 2019 it was PLN 9 billion. The revenues of urban-rural and rural gminas were at a similar level (respectively: PLN 5.4 billion and PLN 5.2 billion), however, we should remember that there are more than twice as many rural gminas.

The share of revenues from the real estate tax in gminas' own revenues amounted on average to $30.4 \%$, 
Table 5

Share of Revenue Lost by Polish Gminas due to Tax Expenditures in Local Taxes in Own Revenues and Local Taxes, according to Gmina Types in the 2007-2019 Period (in \%)

\begin{tabular}{|c|c|c|c|c|c|c|c|c|c|c|c|c|c|}
\hline Type & 2007 & 2008 & 2009 & 2010 & 2011 & 2012 & 2013 & 2014 & 2015 & 2016 & 2017 & 2018 & 2019 \\
\hline \multicolumn{14}{|c|}{ In relation to own revenue } \\
\hline Gminas, total & 6.87 & 6.93 & 7.80 & 7.91 & 7.50 & 8.25 & 8.07 & 7.39 & 7.57 & 5.98 & 5.53 & 5.40 & 5.19 \\
\hline Cities with poviat rights & 2.89 & 2.40 & 2.88 & 3.03 & 3.00 & 2.55 & 2.44 & 2.31 & 2.61 & 2.03 & 1.90 & 1.84 & 1.78 \\
\hline Urban gminas & 7.93 & 7.00 & 8.24 & 9.20 & 8.13 & 7.62 & 7.50 & 6.81 & 7.31 & 6.08 & 5.60 & 5.58 & 5.50 \\
\hline Urban-rural gminas & 11.82 & 11.80 & 12.63 & 14.01 & 12.05 & 13.32 & 13.02 & 11.84 & 12.29 & 9.68 & 8.84 & 9.16 & 8.46 \\
\hline Rural gminas & 13.42 & 15.46 & 16.81 & 14.48 & 14.53 & 18.14 & 17.51 & 16.03 & 15.42 & 11.91 & 11.04 & 10.40 & 10.05 \\
\hline \multicolumn{14}{|c|}{ In relation to the revenue from discussed local taxes } \\
\hline Gminas, total & 20.34 & 20.89 & 21.48 & 20.88 & 20.36 & 21.44 & 21.40 & 20.46 & 20.59 & 16.70 & 15.88 & 16.53 & 16.57 \\
\hline Cities with poviat rights & 11.47 & 9.73 & 10.48 & 10.36 & 10.55 & 8.56 & 8.33 & 8.20 & 9.25 & 7.38 & 7.12 & 7.35 & 7.48 \\
\hline Urban gminas & 21.33 & 19.23 & 20.89 & 21.98 & 20.25 & 18.69 & 18.88 & 18.12 & 18.69 & 15.92 & 15.07 & 15.95 & 16.19 \\
\hline Urban-rural gminas & 26.48 & 27.10 & 27.12 & 29.04 & 26.18 & 27.91 & 27.76 & 26.36 & 26.68 & 21.60 & 20.26 & 22.21 & 21.33 \\
\hline Rural gminas & 27.79 & 33.05 & 33.08 & 28.82 & 30.00 & 35.79 & 35.42 & 33.69 & 32.12 & 25.79 & 24.48 & 24.54 & 25.05 \\
\hline
\end{tabular}

Table 6

Dynamics of Own Revenue and Tax Expenditures in the 2007-2019 Period according to Gmina Types (in \%)

\begin{tabular}{|c|c|c|c|c|c|c|c|c|c|c|c|c|c|}
\hline Type & 2007 & 2008 & 2009 & 2010 & 2011 & 2012 & 2013 & 2014 & 2015 & 2016 & 2017 & 2018 & 2019 \\
\hline \multicolumn{14}{|c|}{ Own revenue dynamics (previous year $=100$ ) } \\
\hline Gminas, total & 100.00 & 108.44 & $96.61^{*}$ & 101.34 & 107.54 & 105.02 & 108.26 & 108.39 & 100.89 & 105.46 & 107.49 & 109.71 & 107.25 \\
\hline Cities with poviat rights & 100.00 & 106.29 & $95.44^{*}$ & 100.01 & 105.56 & 102.46 & 107.40 & 109.04 & 101.43 & 104.80 & 107.51 & 110.67 & 106.63 \\
\hline Urban gminas & 100.00 & 108.47 & $96.34^{*}$ & 103.14 & 107.97 & 104.74 & 107.07 & 106.62 & $97.67^{*}$ & 105.30 & 105.87 & 108.56 & 106.17 \\
\hline Urban-rural gminas & 100.00 & 110.40 & $98.89^{*}$ & 102.03 & 110.11 & 107.81 & 108.54 & 108.17 & 101.28 & 105.95 & 108.53 & 109.07 & 108.15 \\
\hline Rural gminas & 100.00 & 113.24 & $98.05^{\star}$ & 102.97 & 110.17 & 109.36 & 111.11 & 108.41 & 101.62 & 106.71 & 107.64 & 108.86 & 108.66 \\
\hline \multicolumn{14}{|c|}{ Tax expenditures' dynamics (previous year $=100$ ) } \\
\hline Gminas, total & 100.00 & 109.41 & 108.79 & 102.80 & 101.90 & 115.52 & 105.93 & $99.25^{\star}$ & 103.37 & $83.34^{*}$ & $99.39^{*}$ & 107.19 & 103.06 \\
\hline Cities with poviat rights & 100.00 & $88.23^{*}$ & 114.48 & 105.02 & 104.85 & $87.01^{*}$ & 102.54 & 103.30 & 114.72 & $81.57^{*}$ & 100.63 & 106.80 & 103.45 \\
\hline Urban gminas & 100.00 & $95.81^{*}$ & 113.43 & 115.06 & $95.44^{*}$ & $98.22^{*}$ & 105.34 & $96.83^{*}$ & 104.75 & $87.69^{*}$ & $97.52^{*}$ & 108.17 & 104.49 \\
\hline Urban-rural gminas & 100.00 & 110.19 & 105.84 & 113.20 & $94.76^{\star}$ & 119.09 & 106.10 & $98.42^{*}$ & 105.06 & $83.52^{*}$ & $99.02^{\star}$ & 113.08 & $99.91^{*}$ \\
\hline Rural gminas & 100.00 & 130.43 & 106.58 & $88.71^{*}$ & 110.56 & 136.54 & 107.20 & $99.27^{\star}$ & $97.73^{*}$ & $82.42^{\star}$ & $99.85^{\star}$ & 102.50 & 105.02 \\
\hline
\end{tabular}

Note: ${ }^{\star}$ categories that showed a downward trend in each year.

and in revenues from local taxes (which could be changed through taxing power) as much as $87.5 \%$. Taking into account the particular types of gminas, the real estate tax is most significant for urban-rural gminas (on average $37 \%$ of own revenue) and towns with poviat rights (on average over $95 \%$ of revenue in local taxes with taxing power). The highest level of real estate tax revenue per capita was in cities with poviat rights (PLN 720 in 2019), while in rural gmi- nas had the lowest (PLN 480 in 2019).

Observing the importance of the tools of local tax policy (Tables 7 and 8 ), one can see that gminas made greater use of the power to reduce rates than of other tools - these were usually of discretionary nature.

In the studied period, the fiscal effects of the use of tax power instruments in the real estate tax in all gminas amounted to PLN 39.5 billion (PLN 27.16 billion as a result of lowering the upper tax rates and PLN 12.34 billion 
as a result of reliefs and exemptions and tools of the tax ordinance). The enactment of lower real estate tax rates resulted in a lost opportunity to generate $11.5 \%$ more tax revenue. The application of other tax policy instruments affected the revenues from real estate tax to a lesser extent - the revenues were reduced by about $5.2 \%$. The instruments of taxing power exercised by the gminas in the form of lowering the upper tax rates had the greatest impact on the revenues obtained in rural gminas - a mean of $19.6 \%$ of the revenues from the real estate tax. At the opposite extreme of this analysis, however, are cities with poviat rights, where the fiscal impact was much lower than in other types of gminas - a mean of $4.14 \%$ in relation to real estate tax revenue. The data presenting the relation of the financial effects of the use of taxing power instruments to the real estate tax revenues of gminas shows that in recent years (since 2016) this relation has been clearly decreasing. Thus, the activity of local authorities in conducting tax policy has decreased, reducing the value of the use of tax expenditures.

For the correlation analysis of the impact of tax expenditures (tax rate reductions, allowances, and exemptions) on income, data were defined for which signaificant correlations were sought. First, the source data:

1) D - tax revenue (receipts)

2) U - tax expenditures

3) $\quad \mathrm{D} 1(\mathrm{r})=\mathrm{D}(\mathrm{r})-\mathrm{D}(\mathrm{r}-1), \mathrm{r}=2008, \ldots, 2019$.

4) $\mathrm{U} 1(\mathrm{r})=\mathrm{U}(\mathrm{r})-\mathrm{U}(\mathrm{r}-1), \mathrm{r}=2008, \ldots, 2019$.

5) $\mathrm{UD}(\mathrm{r})=\mathrm{U}(\mathrm{r}) / \mathrm{D}(\mathrm{r}), \mathrm{r}=2007, \ldots, 2019$.

6) $\mathrm{D} 2(\mathrm{r})=\mathrm{D} 1(\mathrm{r})-\mathrm{D} 1(\mathrm{r}-1), \mathrm{r}=2009, \ldots, 2019$

7) $\mathrm{UD} 1(\mathrm{r})=\mathrm{UD}(\mathrm{r})-\mathrm{UD}(\mathrm{r}-1), \mathrm{r}=2008, \ldots, 2019$

Data D and U refer to real estate tax, agricultural tax, forest tax, tax on means of transport, collected from legal persons and natural persons (calculated separately and then as a sum from all taxpayers).

The study found significant correlations (Pearson's linear correlation), indicating that the local tax policy of using tax expenditures in a particular year influences the positive revenue trend in the following year. However, these dependencies relate only to the real estate tax and the tax on means of transport.

For real estate tax data collected from corporate entities, the correlations are as follows:
$\operatorname{Corr}\left(\mathrm{UD}(\mathrm{r}-1)_{\mathrm{CwPR}} ; \mathrm{D} 1(\mathrm{r})_{\mathrm{CwPR}}\right)=0.6844(\mathrm{p}=0.007)$

$\operatorname{Corr}\left(\mathrm{UD}(\mathrm{r}-1)_{\mathrm{UG}} ; \mathrm{D} 1(\mathrm{r})_{\mathrm{UG}}\right)=0.4111(\mathrm{p}=0.09)$

$\operatorname{Corr}\left(\mathrm{U} 1(\mathrm{r}-1)_{\mathrm{UG}} ; \mathrm{D} 1(\mathrm{r})_{\mathrm{UG}}\right)=0.4162(\mathrm{p}=0.10)$

For data on the tax on means of transport collected from legal persons, the correlations are as follows:

$\operatorname{Corr}\left(\mathrm{UD}(\mathrm{r}-1)_{\mathrm{CwPR}} ; \mathrm{D} 1(\mathrm{r})_{\mathrm{CwPR}}\right)=0.7903(\mathrm{p}=0.001)$, $\operatorname{Corr}\left(\mathrm{U} 1(\mathrm{r}-1)_{\mathrm{UG}} ; \mathrm{D} 1(\mathrm{r})_{\mathrm{UG}}\right)=0.4788(\mathrm{p}=0.068)$,

For real estate tax data collected from natural persons, the correlations are as follows:

$\operatorname{Corr}\left(\mathrm{UD}(\mathrm{r}-1)_{\mathrm{CwPR}} ; \mathrm{D} 1(\mathrm{r})_{\mathrm{CwPR}}\right)=0.8103(\mathrm{p}=0.0007)$,

$\operatorname{Corr}\left(\mathrm{UD}(\mathrm{r}-1)_{\mathrm{UG}} ; \mathrm{D} 1(\mathrm{r})_{\mathrm{UG}}\right)=0.7870(\mathrm{p}=0,0012)$,

$\operatorname{Corr}\left(\mathrm{UD}(\mathrm{r}-1)_{\mathrm{RG}} ; \mathrm{D} 1(\mathrm{r})_{\mathrm{RG}}\right)=0.8050(\mathrm{p}=0.0008)$,

$\operatorname{Corr}\left(\mathrm{UD}(\mathrm{r}-1)_{\mathrm{U}-\mathrm{RG}} ; \mathrm{D} 1(\mathrm{r})_{\mathrm{U}-\mathrm{RG}}\right)=0.8523(\mathrm{p}=0.0002)$,

$\operatorname{Corr}\left(\mathrm{U} 1(\mathrm{r}-1)_{\mathrm{UG}} ; \mathrm{D} 1(\mathrm{r})_{\mathrm{UG}}\right)=0.3929(\mathrm{p}=0.116)$,

$\operatorname{Corr}\left(\mathrm{UD} 1(\mathrm{r}-1)_{\mathrm{UG}} ; \mathrm{D} 2(\mathrm{r})_{\mathrm{UG}}\right)=0.4990(\mathrm{p}=0.059)$,

For data on the tax on means of transport collected from natural persons, the correlations are as follows:

$$
\begin{aligned}
& \operatorname{Corr}\left(\mathrm{U} 1(\mathrm{r}-1)_{\mathrm{CwPR}} ; \mathrm{D} 1(\mathrm{r})_{\mathrm{CwPR}}\right)=0.4562(\mathrm{p}=0.079), \\
& \operatorname{Corr}\left(\mathrm{U} 1(\mathrm{r}-1)_{\mathrm{UG}} ; \mathrm{D} 1(\mathrm{r})_{\mathrm{UG}}\right)=0.7099(\mathrm{p}=0.007), \\
& \operatorname{Corr}\left(\mathrm{U} 1(\mathrm{r}-1)_{\mathrm{RG}} ; \mathrm{D} 1(\mathrm{r})_{\mathrm{RG}}\right)=0.7432(\mathrm{p}=0.004), \\
& \operatorname{Corr}\left(\mathrm{U} 1(\mathrm{r}-1)_{\mathrm{U}-\mathrm{RG}} ; \mathrm{D} 1(\mathrm{r})_{\mathrm{U}-\mathrm{RG}}\right)=0.6441(\mathrm{p}=0.016), \\
& \operatorname{Corr}\left(\mathrm{UD} 1(\mathrm{r}-1)_{\mathrm{CwPR}} ; \mathrm{D} 2(\mathrm{r})_{\mathrm{CwPR}}\right)=0.5265(\mathrm{p}=0.048), \\
& \operatorname{Corr}\left(\mathrm{UD} 1(\mathrm{r}-1)_{\mathrm{UG}} ; \mathrm{D} 2(\mathrm{r})_{\mathrm{UG}}\right)=0.5546(\mathrm{p}=0.038),
\end{aligned}
$$

For real estate tax data collected from all taxpayers, the correlations are as follows:

$$
\begin{aligned}
& \operatorname{Corr}\left(\mathrm{UD}(\mathrm{r}-1)_{\mathrm{CwPR}} ; \mathrm{D} 1(\mathrm{r})_{\mathrm{CwPR}}\right)=0.7540(\mathrm{p}=0.002) \\
& \operatorname{Corr}\left(\mathrm{UD}(\mathrm{r}-1)_{\mathrm{UG}} ; \mathrm{D} 1(\mathrm{r})_{\mathrm{UG}}\right)=0.5659(\mathrm{p}=0.028) \\
& \operatorname{Corr}\left(\mathrm{UD}(\mathrm{r}-1)_{\mathrm{RG}} ; \mathrm{D} 1(\mathrm{r})_{\mathrm{RG}}\right)=0.4134(\mathrm{p}=0.091) \\
& \operatorname{Corr}\left(\mathrm{U} 1(\mathrm{r}-1)_{\mathrm{UG}} ; \mathrm{D} 1(\mathrm{r})_{\mathrm{UG}}\right)=0.4257(\mathrm{p}=0.096) \\
& \operatorname{Corr}\left(\mathrm{UD} 1(\mathrm{r}-1)_{\mathrm{UG}} ; \mathrm{D} 2(\mathrm{r})_{\mathrm{UG}}\right)=0.3982(\mathrm{p}=0.113)
\end{aligned}
$$

For data on the tax on means of transport collected from all taxpayers, the correlations are as follows:

$$
\begin{aligned}
& \operatorname{Corr}\left(\mathrm{UD}(\mathrm{r}-1)_{\mathrm{CwPR}} ; \mathrm{D} 1(\mathrm{r})_{\mathrm{CwPR}}\right)=0.8118(\mathrm{p}=0.0007) \\
& \operatorname{Corr}\left(\mathrm{U} 1(\mathrm{r}-1)_{\mathrm{UG}} ; \mathrm{D} 1(\mathrm{r})_{\mathrm{UG}}\right)=0.7582(\mathrm{p}=0.0034), \\
& \operatorname{Corr}\left(\mathrm{UD} 1(\mathrm{r}-1)_{\mathrm{CwPR}} ; \mathrm{D} 2(\mathrm{r})_{\mathrm{CwPR}}\right)=0.5147(\mathrm{p}=0.053), \\
& \operatorname{Corr}\left(\mathrm{UD} 1(\mathrm{r}-1)_{\mathrm{RG}} ; \mathrm{D} 2(\mathrm{r})_{\mathrm{RG}}\right)=0.5805(\mathrm{p}=0.031)
\end{aligned}
$$


Table 7

Share of the Value of Revenue Lost by Polish Gminas due to Real Estate Tax Expenditures (tax rate reductions) in the Real Estate Tax, according to Gmina Types in the 2007-2019 Period (in \%)

\begin{tabular}{lcccccccccccccc}
\hline Type & $\mathbf{2 0 0 7}$ & $\mathbf{2 0 0 8}$ & $\mathbf{2 0 0 9}$ & $\mathbf{2 0 1 0}$ & $\mathbf{2 0 1 1}$ & $\mathbf{2 0 1 2}$ & $\mathbf{2 0 1 3}$ & $\mathbf{2 0 1 4}$ & $\mathbf{2 0 1 5}$ & $\mathbf{2 0 1 6}$ & $\mathbf{2 0 1 7}$ & $\mathbf{2 0 1 8}$ & $\mathbf{2 0 1 9}$ \\
\hline Gminas, total & 12.91 & 11.64 & 12.05 & 12.81 & 13.53 & 11.93 & 12.31 & 12.34 & 13.03 & 10.09 & 9.25 & 9.80 & 9.97 & \\
Cities with poviat rights & 6.16 & 4.91 & 5,11 & 5.09 & 5.81 & 3.93 & 3.72 & 3.75 & 4.17 & 2.71 & 2.45 & 2.89 & 3,15 \\
Urban gminas & 13.16 & 11.87 & 12.64 & 13.30 & 13.58 & 12.14 & 12.30 & 12.12 & 12.51 & 10.19 & 9.25 & 9.90 & 10.02 \\
Urban-rural gminas & 18.66 & 17.13 & 17.19 & 19.17 & 19.63 & 17.79 & 18.82 & 18.60 & 20.01 & 15.25 & 13.78 & 14.76 & 14.69 \\
Rural gminas & 19.87 & 18.90 & 19.64 & 20.64 & 21.88 & 20.78 & 21.30 & 21.66 & 22.17 & 17.89 & 16.39 & 16.76 & 16.92 \\
\hline
\end{tabular}

Source: Own compilation based on data from Poland's Ministry of Finance.

\section{Table 8}

Share of the Value of Revenue Lost by Polish Gminas due to Real Estate Tax Expenditures (Exemptions, Credit, etc.) in the Real Estate Tax, According to Gmina Types in the 2007-2019 Period (in \%)

\begin{tabular}{lccccccccccccccc}
\hline Type & $\mathbf{2 0 0 7}$ & $\mathbf{2 0 0 8}$ & $\mathbf{2 0 0 9}$ & $\mathbf{2 0 1 0}$ & $\mathbf{2 0 1 1}$ & $\mathbf{2 0 1 2}$ & $\mathbf{2 0 1 3}$ & $\mathbf{2 0 1 4}$ & $\mathbf{2 0 1 5}$ & $\mathbf{2 0 1 6}$ & $\mathbf{2 0 1 7}$ & $\mathbf{2 0 1 8}$ & $\mathbf{2 0 1 9}$ \\
\hline Gminas, total & 6.55 & 5.85 & 6.46 & 7.34 & 5.69 & 5.50 & 5.43 & 5.18 & 5.33 & 4.43 & 4.34 & 4.05 & 3.89 \\
Cities with poviat rights & 4.35 & 3.31 & 3.80 & 3.78 & 3,13 & 2.79 & 2.68 & 2.42 & 2.93 & 2.30 & 2.27 & 1.94 & 1.80 \\
Urban gminas & 6.85 & 5.65 & 6.42 & 6.95 & 4.61 & 4.46 & 4.34 & 3.70 & 3.81 & 3.23 & 3.21 & 3.29 & 3.22 \\
Urban-rural gminas & 7.96 & 7.09 & 7.79 & 11.02 & 6.90 & 6.90 & 6.43 & 6.29 & 6.11 & 5.55 & 5.20 & 5.23 & 4.79 \\
Rural gminas & 9.10 & 9.73 & 10.26 & 10.69 & 10.22 & 10.02 & 10.27 & 10.13 & 9.96 & 7.99 & 7.87 & 7.10 & 7.06 \\
\hline
\end{tabular}

Source: Own compilation based on data from Poland's Ministry of Finance.

The correlation Corr $(\mathrm{UD}(\mathrm{r}-1)$; D1(r)) describes the effect of the \% share of tax expenditures in revenue on tax revenue growth. A significant positive correlation means that increasing the share of tax expenditures in revenue positively influences revenue growth in the following year.

The correlation Corr $(\mathrm{U} 1(\mathrm{r}-1)$; D1(r)) describes the effect of the \% increase in tax expenditures on revenue growth. A significant positive correlation means that increasing the $\%$ increase in tax expenditures has a positive effect on revenue growth in the following year.

The correlation Corr(UD1(r - 1); D2(r)) describes the effect of an increase in the \% share of tax expenditures in revenue on the trend in revenue growth. A significant positive correlation means that an increase in the $\%$ share of tax expenditures in revenue has a positive effect on the incremental trend in revenue growth in the following year.

Each of these correlations describes the de facto response of local tax collection to the stimulus of using tax expenditures, which is the essence of local tax policy. If some form of tax expenditures by means of increasing tax rate reductions and tax credits influence positive trends in the collection of these taxes in subsequent years, it undoubtedly makes local tax policy effective and desirable.

Tax expenditures - obviously - reduce gminas' financial resources from financial taxes in the year they are applied. In the following years, however, as is evident, they increase revenue from taxes. Referring to the essence of tax expenditures and the reasons for their application, it is worth noting the economic and social premises for the application of such tools. In order to illustrate this issue, a survey was used, as an attempt to determine the impact of certain considerations regarding tax expenditures in real estate tax in the form of rate reductions, their differentiation, and the use of reliefs and tax exemptions ${ }^{10}$. The questionnaire considered 5 items. Gminas had to assess:

1. incentive to attract entrepreneurs,

2. incentive for the development of entrepreneurship in the gmina,

3. incentive for residents to settle down,

4. improvement of the material situation of the inhabitants,

5. increase in budget revenues in the future. 


\section{Figure 4}

Evaluation of the Impact of Attracting Businesses to the Gmina through the Use of Real Estate Tax Preferences (responses of Gminas of Each Type $=100$ )

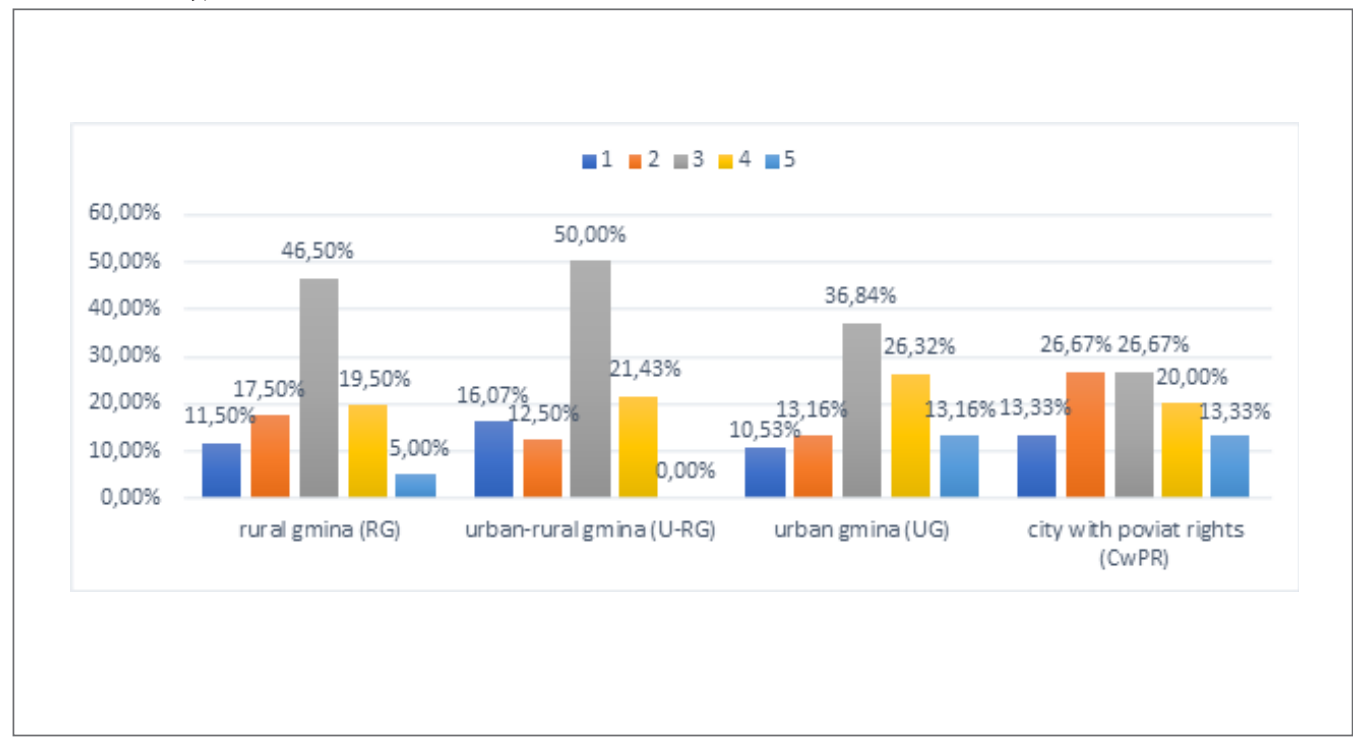

Source: Gospodarka finansowa gmin w Polsce [Financial management of gminas in Poland]. KZiF/S20/1.15,

P. Felis (study leader), E. Malinowska-Misiąg, G. Otczyk. Unpublished materials.

In terms of assessing the impact of attracting businesses through the use of real estate tax preferences, respondents indicated that there is such an impact, but it is usually a medium one, as indicated by $45 \%$ of all gminas. Very low impact was indicated by $12 \%$ of respondents, and low impact by $17 \%$. In contrast, $21 \%$ of the gminas indicated a high and only $5 \%$ a very high impact (Figure 4).

The second item (which aimed to examine the use of tax preferences towards supporting business activity) was treated as a high impact one (Figure 5). High impact in deciding real estate tax rates was indicated by as many as $30 \%$ of all gminas and $8 \%$ indicated very high impact. However, a low impact was indicated by only $12 \%$ of gminas, and a very low impact by less than $4 \%$. A significant number of gminas indicated a medium impact ( $46 \%$ of all gminas).

In terms of attracting new residents, the importance was reported as very low by $4 \%$ of the gminas, and as low by $13 \%$. The remaining gminas indicated that this premise has a greater impact (Figure 6).
The second rationale aimed at tax preferences for natural persons tended to have an average impact on tax decisions in this respect. Cities with poviat rights paid less attention to this premise (Figure 7).

Gminas were consistent in claiming that when applying tax preferences in real estate tax, they were generally aimed at increasing future budget revenues (Figure 8) - which corresponds to the conclusions arising from the correlation analysis.

\section{Conclusions}

The current study presents the issue of tax expenditures - an instrument of fiscal policy that allows to achieve specific socio-economic objectives. The study focused on the local level budgets in Poland with emphasis on the tax system in the context of using specific structures to build the revenue potential of gminas and to support and stimulate local development.

The research on tax expenditures at the local level is fully justified not only from the point 


\section{Figure 5}

Evaluation of the Impact of Developing Businesses in the Gmina through the Use of Real Estate Tax Preferences (Responses of Gminas of Each Type =100)

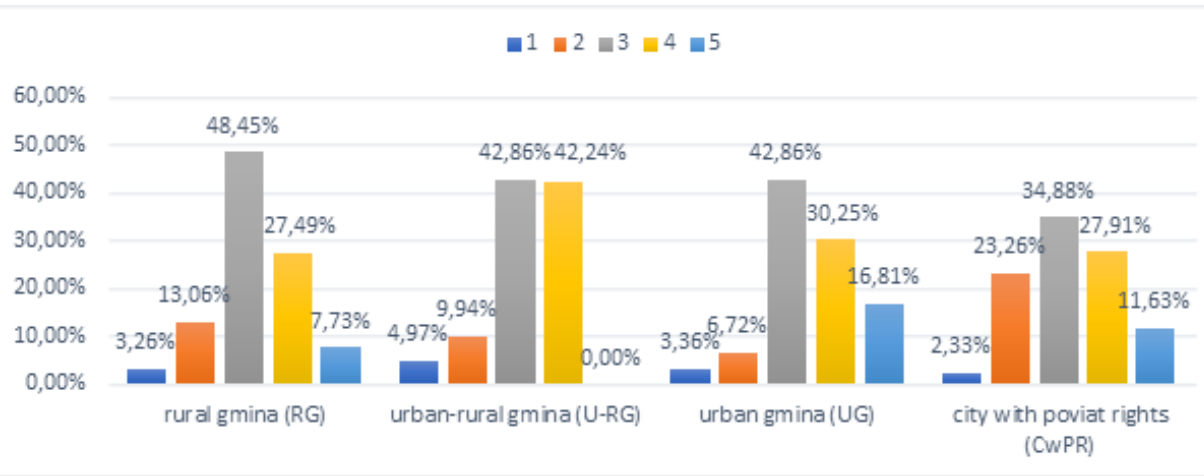

Source: Gospodarka finansowa gmin w Polsce [Financial management of gminas in Poland]. KZiF/S20/1.15,

P. Felis (study leader), E. Malinowska-Misiąg, G. Otczyk. Unpublished materials.

\section{Figure 6}

Evaluation of the Impact of Encouraging Residents to Settle Down through the Use of Real Estate Tax Preferences by the Gmina (Responses of Gminas of Each Type =100)

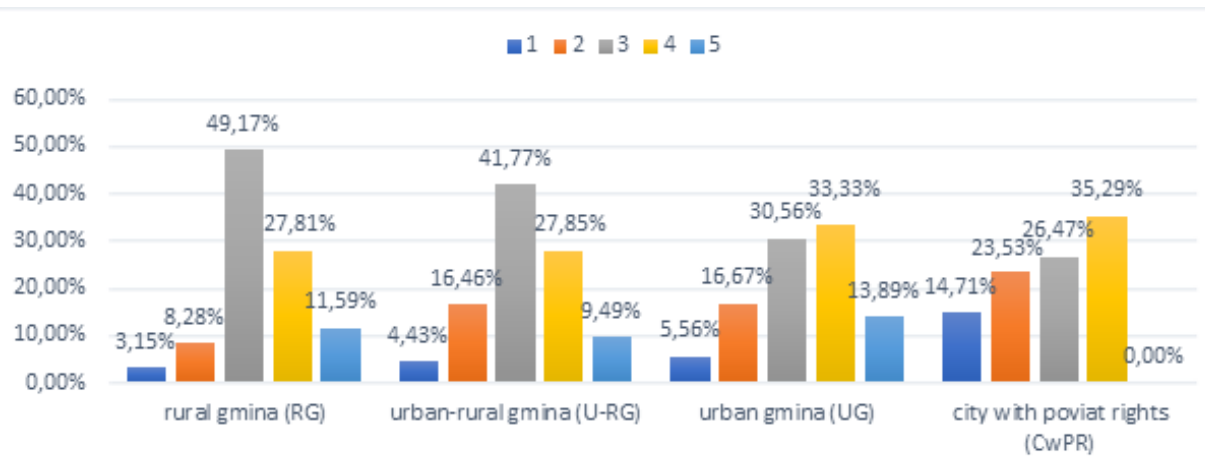

Source: Gospodarka finansowa gmin w Polsce [Financial management of gminas in Poland]. KZiF/S20/1.15, P. Felis (study leader), E. Malinowska-Misiąg, G. Otczyk. Unpublished materials. 


\section{Figure 7}

Evaluation of the Impact of the Will to Improve the Financial Situation of Residents through the Use of Real Estate Tax Preferences in Gminas (Responses of Gminas of Each Type $=100$ )

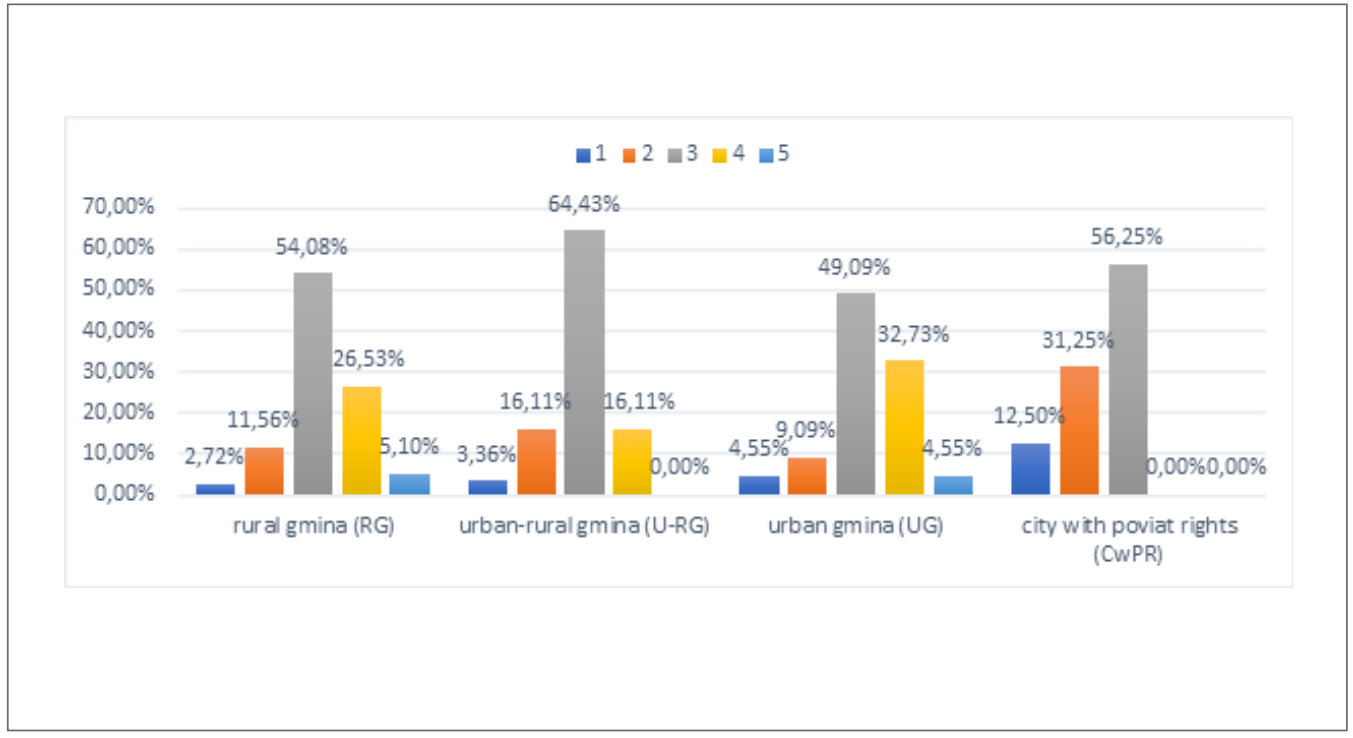

Source: Gospodarka finansowa gmin w Polsce [Financial management of gminas in Poland]. KZiF/S20/1.15, P. Felis (study leader), E. Malinowska-Misiąg, G. Otczyk. Unpublished materials.

\section{Figure 8}

Evaluation of the Impact of the Desire to Increase Budget Revenues in the Future through the Use of Real Estate Tax Preferences in the Gminas (Responses of Gminas of Each Type =100)

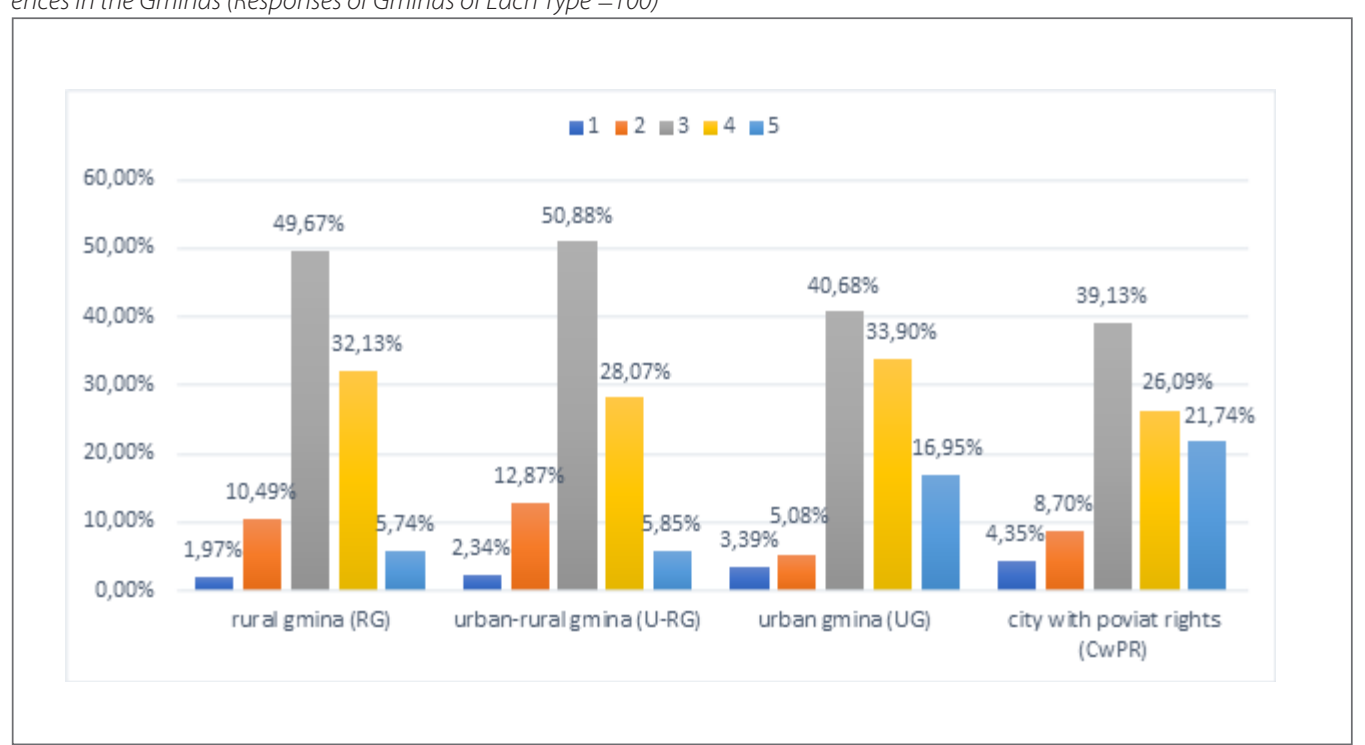

Source: Gospodarka finansowa gmin w Polsce [Financial management of gminas in Poland]. KZiF/S20/1.15, P. Felis (study leader), E. Malinowska-Misiąg, G. Otczyk. Unpublished materials. 
of view of estimating the costs of the tax system (which, when compared with the revenue effects, may be a basis for a reliable assessment of the effectiveness and efficiency of the tax system), but also in the context of the important principle for the functioning of local governments - financial independence. It is realized, among other things, via the taxing power granted to local units. It should be stressed, however, that the issue of the division of taxing power between the state and local government must be considered not only from the perspective of the financial independence of local communities, but also from a broader perspective, taking into account the principles of operation and scope of the public financial system.

Local government units in Poland do not have full taxing power, moreover, it is only available to gminas that have their own tax revenues. An assessment of the revenue structure of gminas leaves no doubt that the scope of their financial autonomy is low. In principle, all local taxes - except the real estate tax - are becoming less prominent as sources of budget revenue. The permanent and significant place in the system of own revenues of the real estate tax allowed gminas to influence its fiscal efficiency. The value of lost revenue from the use of tax expenditures in this tax was by far the largest, and the dominant form of TEs was the reduction and differentiation of tax rates.

The TEs instruments used by gminas have a negative financial impact in the short term, which limits the ability of gminas to perform public tasks. It is important that this temporary loss of part of the revenue translate into achieving the goals set by the gmina and expanding the future tax base. Improving the competitiveness of a local unit compared to others is an opportunity to attract businesses and new residents, which means increased tax revenue for the gmina in the future. Most studies show that the effectiveness of tax expenditures as an instrument of local tax policy is low. There is no obvious link between the TEs used and the effects of local tax policy making. The analyses conducted in the current study partially confirm the findings of other researchers.

First, gminas made little use of tax expenditures in most local taxes. However, it should be noted that their scope was highly diversified - depending on the type of gmina, its potential (attractiveness for the location of various socio-economic and personal undertakings), the type of real estate located in the gmina and the (registered) means of transport used.

Second, tax expenditures in local taxes are not only the effect of using the powers resulting from the taxing power granted to gminas, but also certain tax preferences allowed by the legislator. This issue also requires in-depth research, because such tax expenditures used in the construction of local taxes, as well as in PIT and CIT taxes that are important for gminas, although they support specific socio-economic areas, they are outlined and implemented at the central level. When these objectives are not in line with local policy, tax expenditures contributing to an obvious reduction of gmina revenues will be perceived by local communities as an unjustified cost in the first place ${ }^{11}$.

Third, the results of the correlation analysis indicate some relationship between the used tax expenditures in local tax policy and some of its effects. The values of Pearson correlation coefficients presented in the study can be used for the preliminary assessment of the level of linear dependence between the variables adopted to describe the increase in revenue potential of gminas (one of the objectives of the local tax policy) and TEs. The presented correlations (impact of $\%$ share of tax expenditures in revenues on tax revenue growth; impact of \% share of growth in tax expenditures on revenue growth; impact of $\%$ share of growth in tax expenditures in revenues on the trend of revenue growth change) confirm the effectiveness of TEs in some taxes (real estate and means of transport taxes) in terms of improving the trend of tax revenues in the future.

Fourth, the cited surveys show that gminas are not necessarily lacking in deliberate local tax policy making. Admittedly, it does happen quite often that decisions are taken for political reasons, but this happens mostly in small gminas. Thus, it appears that gminas, while defining the objectives of the local tax policy, consciously take into account fiscal premises and stimulation for companies and the population. 


\section{Footnotes}

${ }^{1}$ In Poland, similar research was conducted, among others, by D. Wyszkowska and A. Wyszkowski (2021) and R. Dziemianowicz and R. Budlewska (2015).

${ }^{2}$ The powers of the tax authority, referred to in the Tax Ordinance of Poland as "reliefs in repayment of tax liabilities" are uniform for each tax (including local taxes) and consist in the possibility of postponing the date of payment, spreading into instalments the tax or tax arrears, remission in full or in part of the tax arrears, interest for late payment, or the prolongation fee (Tax Ordinance Act, 1997).

${ }^{3} J$. Dziuba (2016), among others, writes on the subject of taxing power and the resulting consequences for local government units in Poland.

${ }^{4}$ The reduction in the amount of tax varies from $25 \%$ of the amount of annual tax (for 20 to 49 trips made by rail in a tax year) to $100 \%$ of the amount of annual tax (for 100 trips and more).

${ }^{5}$ However, there is a problem with the consistency of some of the data. Aggregate data appear later and are usually adjusted relative to previously published unit bases. The majority of these were data from budget reports - Reports Rb-27s on the execution of the budget revenue plan of a local government unit. It was supplemented with data on the value of tax preferences in the Polish tax system.

${ }^{6}$ These revenues are included in section 756 of the $\mathrm{Rb}-27 \mathrm{~s}$ report. This category includes revenues from real estate tax, agricultural tax, forest tax, tax on means of transport, tax on civil law transactions, tax on inheritance and donations, fixed amount tax, PIT and CIT shares, and various local fees.

${ }^{7}$ The survey was conducted at the end of 2020 as the next stage of the scientific study Gospodarka finansowa gmin w Polsce [Financial management of gminas in Poland]. KZiF/S20/1.15, Authors:
P. Felis (study leader), E. Malinowska-Misiąg, G. Otczyk. Unpublished materials.

${ }^{8}$ These data, however, according to the quoted publication, concern only real estate tax, agricultural tax and forest tax. The preferences resulting from the tax on means of transport were therefore disregarded.

${ }^{9}$ The issue of income potential of gminas in Poland is explored in detail by E. MalinowskaMisiąg (2019).

${ }^{10}$ The assessment of gminas was based on a 5-level scale: 1 - very low impact, 2 - low impact, 3 - medium impact, 4 - high impact, and 5 - very high impact.

${ }^{11}$ The problem was noted and partially studied by Dziemianowicz and Budlewska (2015).

\section{References}

Arvin, M. B., Pradhan, R. P., \& Nair, M. S. (2021). Are there links between institutional quality, government expenditure, tax revenue and economic growth? Evidence from low-income and lower middle-income countries. Economic Analysis and Policy, 70, 468-489. https://doi.org/10.1016/j. eap.2021.03.011

Banaszewska, M. (2021). Preferential tax treatment - a political or economic tool? Regional Studies, 1-14. https://doi.org/10.1080/00343404.2021.19 78420

Barrios, S., Coda Moscarola, F., Figari, F., Gandulia, L., \& Riscado, S. (2020). The fiscal and equity impact of social tax expenditures in the EU. Journal of European Social Policy, 30(3), 355-369. https:// doi.org/10.1177\%2F0958928719891341

Barrios, S., Coda Moscarola, F., Figari, F., \& Gandullia, L. (2020). Size and distributional pattern of pension-related tax expenditures in European countries. International Tax and Public Finance, 27(5), 1287-1320. https://doi.org/10.1007/ s10797-019-09580-7

Benjamin, L. M., \& Posner, P. L. (2018). Tax Expenditures and Accountability: The Case of the Ambivalent Principals. Journal of Public Administration Research and Theory, 28(4), 569-582. https://doi. org/10.1093/jopart/muy040 
Brzozowska, K., Kogut-Jaworska, M. (2016). Władztwo podatkowe $\mathrm{w}$ ocenie samodzielności dochodowej gmin $\mathrm{w}$ Polsce [Tax Control in Evaluation of Financial Autonomy of Communes in Poland]. Annales Universitatis Mariae Curie-Skłodowska, Sectio H Oeconomia, Vol. L.,1, 327-337. http://dx.doi. org/10.17951/h.2016.50.1.327

Burman, L. E. (2003). Is the Tax Expenditure Concept Still Relevant? National Tax Journal, 56(3), 613-627. JSTOR.

Bykov, S. S., \& Zimmermann, H. (2018). Tax expenditure as a problem in intergovernmental relations. Journal of Tax Reform, 1(4), 27-44.

Decker, J. W. (2021). An (in)effective tax and expenditure limit (TEL): Why county governments do not utilize their maximum allotted property tax rate. Public Administration. https://doi.org/10.1111/padm.12756

Dziemianowicz, R., \& Budlewska, R. (2015). Czy tax expenditures stosowane $\mathrm{w}$ podatkach państwowych mają wpływ na dochody JST? Przyczynek do dyskusji [Do tax expenditures used in the state taxes affect incomes of the self-government units? A contribution to the discussion]. Prace naukowe Uniwersytetu Ekonomicznego we Wrocławiu, Research Papers of Wrocław University of Economics, 404, 68-85. 10.15611/pn.2015.404.05

Dziemianowicz, R., Wyszkowski, A., \& Budlewska, R. (2014). Tax expenditures jako element konstrukcji polskiego podatku od dochodów osobistych [Tax expenditures as an element of personal income tax in Poland]. Studia Ekonomiczne, 198, 213-224.

Dziuba, J. (2016). Zróżnicowanie fiskalnych skutków polityki podatkowej jednostek samorządu terytorialnego [Differences in fiscal Implications of tax policy in Polish municipalities]. Annales Universitatis Mariae Curie-Skłodowska, Sectio H Oeconomia, 50(1), 351360. http://dx.doi.org/10.17951/h.2016.50.1.351

Felis, P., \& Otczyk, G. (2021). Zróżnicowanie fiskalnych skutków gminnej polityki podatkowej w Polsce [Diversity od fiscal consequences of municipal tax policy in Poland]. Studia BAS, Biuro Analiz Sejmowych, 1(65), 77-102. https://doi.org/10.31268/StudiaBAS.2021.06

Felis, P., Malinowska-Misiąg, E., \& Otczyk, G. (2020). Gospodarka finansowa gmin w Polsce [Financial management of gminas in Poland]. KZiF/ S20/1.15, Materiały niepublikowane.

Felis, P., \& Rosłaniec, H. (2019). Local authority tax policy in Poland. Evidence from the Union of Polish Metropolises. Contemporary Economics, 13(1), 49-62. https://doi.org/10.5709/ce.18979254.298
Felis, P., Gołębiowski, G., \& Stiller, W. (2019). Surface area and value property taxation. The example of Poland and Germany. Analyses and Studies, 2(8), 45-61. 10.33119/ASCASP.2019.2.4

Felis, P., Szlęzak-Matusewicz, J., \& Rosłaniec, H. (2018). Can local tax policy be efficient? Polish Communes' Agricultural Tax Policy. Lex Localis Journal of Local Self-Government, 16(4), 649-671. https://doi.org/10.4335/16.4.649-671(2018)

Felis, P. (2014). The impact of local governments on their own revenue source efficiency. Review of communes in Poland. Business and Economic Horizons, BEH, 10(3-4), 191-201. 10.15208/ beh.2014.16

Gurdal, T., Aydin, M., \& Inal, V. (2021). The relationship between tax revenue, government expenditure, and economic growth in G7 countries: New evidence from time and frequency domain approaches. Economic Change and Restructuring, 54(2), 305-337. https://doi.org/10.1007/s10644020-09280-x

López Pérez, S. D., \& Vence, X. (2021). When harmful tax expenditure prevails over environmental tax: An assessment on the 2014 Mexican fiscal reform. Sustainability, 13(20), 1-17. https://doi. org/10.3390/su132011269

Malinowska-Misiąg, E. (2019). Potencjał dochodowy jednostek samorzadu terytorialnego $w$ Polsce [Revenue potential of local government units in Poland]. Oficyna Wydawnicza SGH.

Matysek, G. (2011). Uwarunkowania skuteczności instrumentów podatkowych [Determinants of Effectiveness of Tax Instruments]. Research Papers of Wrocław University of Economics, 173, 407-414.

Raczkowski, K. (2016). Determinanty efektywności fiskalnej systemu podatkowego [The Determinants of Fiscal Effectiveness of the Tax System]. Annales Universitatis Mariae Curie-Skłodowska, Sectio H Oeconomia, 50(1), 71-81. http://dx.doi. org/10.17951/h.2016.50.1.71

Redonda, A., Diaz de Sarralde, S., Hallerberg, M., Johnson, L., Melamud, A., Rozemberg, R., Schwab, J., \& von Haldenwag, C. (2019). Tax expenditure and the treatment of tax incentives for investment. Economics, 13, 1-11. https://doi.org/10.5018/economics-ejournal.ja.2019-12

Swianiewicz, P., \& Łukomska, J. (2016). Lokalna konkurencja podatkowa [Local tax competition]. Studia Regionalne i Lokalne, 2(64), 5-29. 10.7366/1509499526401

Wyszkowska, D., \& Wyszkowski, A. (2021). Tax expenditures $\mathrm{w}$ podatkach lokalnych $\mathrm{w}$ Polsce jako 
instrument lokalnej polityki podatkowej [Tax expenditures in local taxes in Poland as an instrument of local tax policy]. Studia BAS, Biuro Analiz Sejmowych, 1(65), 103-126. 10.31268/StudiaBAS.2021.07

Wyszkowski, A. (2010). Koncepcja tax expenditures w systemie podatkowym [The concept of tax expenditures in the tax system]. Gospodarka Narodowa. The Polish Journal of Economics, 242(9), 65-82.

Wyszkowski, A. (2012). Podejścia w definiowaniu tax expenditures [Approaches in defining tax expenditures]. Studia Ekonomiczne/Uniwersytet Ekonomiczny w Katowicach, 108 Finanse $w$ niestabilnym otoczeniu-dylematy i wyzwania: finanse publiczne, 406-416.

Villela, L., Lemgruber, A., Jorratt, M. (2010). Tax expenditure budgets concepts and challenges for implementation, IDB Working Paper Series No. IDB-WP-131.

Preferencje podatkowe $\mathrm{w}$ Polsce [Tax preferences in Poland], Nr 8 (2018), www.podatki.gov.pl

Ustawa z dnia 28 lipca 1983 r. o podatku od spadków i darowizn, Dz.U. 2021, poz.1043 [Act of 28 July 1983 on inheritance and donation tax, Journal of Laws 2021, item 1043].

Ustawa z dnia 15 listopada 1984 r. o podatku rolnym, Dz.U. 2020, poz.333 [Act of 15 November 1984 on agricultural tax, Journal of Laws 2020, item 333].

Ustawa z dnia 12 stycznia 1991 r. o podatkach i opłatach lokalnych, Dz.U. 2019, poz.1170 ze zm. [Act of 12 January 1991 on taxes and local fees, Journal of Laws 2019, item 1170 as amended].

Ustawa z dnia 29 sierpnia 1997 r. Ordynacja podatkowa, Dz.U. 2021, poz.1540 ze zm. [Tax Ordinance Act of 29 August 1997, Journal of Laws 2021, item 1540 as amended].

Ustawa z dnia 20 listopada 1998 r. o zryczałtowanym podatku dochodowym od niektórych przychodów osiąganych przez osoby fizyczne, Dz.U. 2021, poz.1993 ze zm. [Act of 20 November 1998 on lump sum income tax on certain income earned by natural persons, Journal of Laws 2021, item 1993, as amended].

Ustawa z dnia 9 września 2000 r. o podatku od czynności cywilnoprawnych, Dz.U. 2020, poz.815 ze zm. [Act of 9 September 2000 on tax on civil law transactions, Journal of Laws 2020, item 815 as amended].

Ustawa z dnia 30 października 2002 r. o podatku leśnym, Dz.U. 2019, poz.888 [Act of 30 October 2002 on forest tax, Journal of Laws 2019, item 888].
Ustawa z dnia 13 listopada 2003 r. o dochodach jednostek samorządu terytorialnego, Dz.U. 2021, poz.1672, ze zm. [Act of 13 November 2003 on revenues of local government units, Journal of Laws 2021, item 1672, as amended]. 